\title{
Predation on artificial nests in open habitats of central Brazil: effects of time and egg size
}

\author{
Cleyton Washington da Silva Oliveira ${ }^{1}$, Glaudson Pereira Almeida ${ }^{1}$, \\ Luciana Vieira de Paiva ${ }^{2}$ \& Leonardo Fernandes França ${ }^{2,3}$ \\ ${ }^{1}$ Curso de Ciências Biológicas, Faculdades Integradas da Terra de Brasília-FTB, \\ CEP 70803-100, Brasilia, DF, Brasil \\ ${ }^{2}$ Departamento de Ciências Animais, Universidade Federal Rural do Semiárido - UFERSA, \\ Av. Francisco Mota, 572, Costa e Silva, CEP 59625-900, Mossoró, RN, Brasil. www.ufersa.edu.br. \\ ${ }^{3}$ Corresponding author: Leonardo Fernandes França, e-mail: franca_lf@ufersa.edu.br
}

OLIVEIRA, C.W.S., ALMEIDA, G.P., PAIVA, L.V. \& FRANÇA, L.F. Predation on artificial nests in open habitats of central Brazil: effects of time and egg size. Biota Neotrop. 13(1): http:/www.biotaneotropica.org. br/v13n1/en/abstract?article+bn03613012013

\begin{abstract}
The accuracy of artificial nests in representing natural patterns of nest predation has been widely studied in temperate regions and egg size is one of the most tested sources of bias. In the neotropics, experiments with artificial nests usually used larger than natural eggs, despite suggestions in literature that the eggs should be similar to those of the local species. Here, we tested the hypothesis of spatial-temporal variation in predation risk of artificial nests in relation to egg size. We used quail (Coturnix coturnix; large), Chestnut-bellied Seedfinch (Oryzoborus angolensis; small) and plasticine (both sizes) eggs placed in artificial nests. We analyzed daily nest survival using models in the Program MARK. The best-fit model included the effects of egg size and the reproductive period on daily survival of artificial nests. Nests with large eggs had greater Daily Survival Estimates (DSE) than nests with small eggs during two times and DSE were smaller early in the reproductive period. DSE of $0.82(95 \% \mathrm{CI}=0.76$ to 0.86$)$ and $0.91(0.87$ to 0.93$)$ were recorded for large eggs at the beginning and end periods compared to 0.72 (0.65 to 0.78$)$ and 0.84 (0.79 to 0.88 ) for small eggs. Birds were more important predators (40\% of records) than mammals and reptiles based on signs left on the plasticine eggs. Our results support the hypothesis that larger eggs are less depredated than small ones in artificial bird nests, even when main predators (birds) are different from those commonly observed in the Neotropics (mammals and reptiles). However, controlling the egg size in experiments with artificial nests may not be sufficient to obtain similar time patterns observed in natural nests studied in the Cerrado.
\end{abstract}

Keywords: bird, Cerrado, neotropical savanna, nest success, reproduction.

OLIVEIRA, C.W.S., ALMEIDA, G.P., PAIVA, L.V. \& FRANÇA, L.F. Predação de ninhos artificiais em hábitats abertos no Brasil Central: efeito temporal e do tamanho do ovo. Biota Neotrop. 13(1): http://www. biotaneotropica.org.br/v13n1/pt/abstract?article+bn03613012013

Resumo: A acurácia de ninhos artificiais em representar padrões naturais de predação de ninhos foi amplamente estudada em regiões temperadas, sendo o tamanho do ovo uma das fontes de erro mais testadas. Nos Neotrópicos, os experimentos com ninhos artificiais geralmente usaram ovos maiores que os naturais, apesar da literatura indicar a necessidade do uso de ovos semelhantes aos das espécies locais. Aqui, testamos hipóteses sobre variação espaço-temporal no risco de predação de ninhos artificiais em função do tamanho do ovo. Para isso, usamos ninhos artificiais com ovos de Codorna (Coturnix coturnix; grandes), Curió (Oryzoborus angolensis; pequenos) e plasticina (ambos tamanhos). Analisamos a sobrevivência diária dos ninhos através de modelos gerados no Programa MARK. O modelo melhor ajustado aos dados incluiu o efeito do tamanho do ovo e do período reprodutivo na sobrevivência diária dos ninhos artificiais. Ninhos com ovos grandes tiveram maiores Estimativas de Sobrevivência Diária (ESD) durante os dois períodos, além disso, as ESD foram menores no início do período reprodutivo. ESD de $0,82(95 \% \mathrm{IC}=0,76$ a 0,86$)$ e $0,91(0,87$ a 0,93$)$ foram registradas para ovos grandes no início e fim da estação reprodutiva, comparado com $0,72(0,65$ a 0,78$)$ e $0,84(0,79$ a 0,88$)$ registradas para ovos pequenos. As aves foram predadores mais importantes ( $40 \%$ dos registros) que os mamíferos e répteis, de acordo com as marcas deixadas nos ovos de plasticina. Nossos resultados dão suporte à hipótese de que ovos grandes são menos predados do que pequenos, mesmo os principais predadores (Aves) tendo sido diferentes do comumente observado nos Neotrópicos (Mamíferos e Répteis). No entanto, controlar o tamanho dos ovos nos experimentos com ninhos artificiais pode não ser suficiente para se obter padrões temporais similares ao observado em ninhos naturais no Cerrado.

Palavras-chave: aves, Cerrado, savana neotropical, sucesso de ninhos, reprodução. 


\section{Introduction}

In the last four decades, experiments with artificial bird nests have been used to test hypotheses of nest predation patterns (reviews in Major \& Kendal 1996, Moore \& Robinson 2004). However, artificial nests differ from natural nests in important ways, including appearance (nest shape and color), scent, egg size and parental activity (Major \& Kendal 1996), which may result in biased estimates of true predation rates (Roper 1992, Haskell 1995, Maier \& DeGraaf 2000). These problems have directed the use of artificial nests to test more restricted hypotheses such as to predict relative impacts between habitat types, or for comparisons between artificial and natural nests (Pärt \& Wretenberg 2002, Batáry \& Báldi 2005, Boyle 2008, Ryder et al. 2010). The effectiveness of artificial nest experiments depend on local and specific agents, and each characteristic of the nest must be tested before local hypotheses on conservation and ecological patterns are evaluated (Major \& Kendal 1996).

Predation on natural bird nests is a frequent cause of low reproductive success in the neotropics (Stutchbury \& Morton 2001). This is also true in open areas of the Cerrado (neotropical savanna), where predation results in $70 \%$ from $90 \%$ of nests lost (Lopes \& Marini 2005, França \& Marini 2009b, Borges \& Marini 2010). In forests, the main nest predators appear to be mammals, snakes and lizards (Robinson \& Robinson 2001, Stake et al. 2004, Robinson et al. 2005). In contrast, in some areas in the Cerrado, birds were the main predators (França et al. 2009). Overall, predation in the Cerrado habitats tended to increase throughout the reproductive period (Borges \& Marini 2010), decrease during nest development (França \& Marini 2009b), and differ between habitats and microhabitats (França \& Marini 2009a, Borges \& Marini 2010). These studies show the importance of predation for population dynamics of neotropical birds and so experiments with artificial nests may be important to understand spatial and temporal patterns of reproductive success.

The few neotropical studies with artificial nests or both natural and artificial nests were conducted in closed forested areas (Roper 2000, Robinson et al. 2005, Alvarez \& Galetti 2007), where birds were not an important set of predators, or in open areas of Cerrado, but not controlling for egg sizes (França \& Marini 2009a). As with natural nests, predation risk was influenced by habitat or nest characteristics (França \& Marini 2009a, Chiarello et al. 2008, Boyle 2008, Alvarez \& Galetti 2007, Robinson et al. 2005). Experiments with artificial nests in the neotropics detect spatial and temporal variation in nest predation risk, yet how these effects resemble those observed for natural nests are unknown. Furthermore, egg size, one of the most tested influences on predation rates (Haskell 1995, Maier \& DeGraaf 2000, Berry \& Lill 2003) was usually overlooked in neotropical studies.

In our study we used the available literature on predation of natural and artificial nests in neotropics to test hypotheses about variation in the predation risk of artificial nests. The tested hypotheses were: (1) predation on artificial nests with large eggs will be less than that on nests with small eggs (Roper 1992, Alvarez \& Galleti 2007); (2) the risk of predation will increase over time during the reproductive season, as observed in some studies with natural nests in neotropical areas (Borges \& Marini 2010, Duca \& Marini 2005); (3) predation risk will be greater in shrubs habitat than in trees, because predation tends to be greater in savanna than in forest (see Duca \& Marini 2005, Robinson et al. 2000, França \& Marini 2009b, Borges \& Marini 2010).

\section{Materials and Methods}

\section{Study area}

Our study was conducted in a Cerrado fragment (Neotropical savanna) of central Brazil ( $\left.15^{\circ} 45^{\prime} \mathrm{S}, 48^{\circ} 04^{\prime} \mathrm{W}\right)$. The area comprises open-cerrado, gallery forests and plantations of Eucaliptus sp. The open-cerrado areas have a grass matrix with sparse Shrub and trees (Ribeiro \& Walter 1998). The gallery forests are perennial closed forests which follow a stream course. The eucalyptus plantations were clear cut, but have been abandoned for at least 10 years and cerrado is in regeneration. In this habitat we observed the occurrence of common birds in the open-cerrado (pers. obs.), however we did not establish relative abundances. The open-cerrado and plantations had no canopy formation.

\section{Experiment design and data sampling}

We built artificial open-cup nests with clusters of local grasses and sewing thread to mimic the shape and size of Lesser Elaenia nests (Elaenia chiriquensis, Lawrence 1865). Nests of this elaenia are the most abundant and found in the region during the time of this study. Her nests are cups with grass stems and spider webs, at an average height of $1.5 \mathrm{~m}$ in shrubs and trees (Medeiros \& Marini 2007). The Lesser Elaenia was also very common in the study area during the breeding season (L.F. França, pers. obs.). Our artificial nests were dipped in a mixture of water and clay and dried in the sun. Afterwards, to reduce human scent, we used latex gloves when touching the nests and eggs (Whelan et al. 1994). Quail eggs (Coturnix coturnix, Linnaeus 1758) were our large egg treatment (25 to $30 \mathrm{~mm}$ in length) and Chestnut-billed Seed-finch eggs (Oryzoborus angolensis, Linnaeus 1766) the small egg treatment (18 to $20 \mathrm{~mm}$ in length). The latter are similar in size and color to those of most local passerine eggs. Also, artificial eggs made of plasticine (white wax modeling clay, ACRILEX ${ }^{\circledR}$ ) were used to identify predators based on the marks left on the eggs.

We used nests with large eggs (one quail egg and one plasticine egg of the same size, shape and colors) and nests with small eggs (one Chestnut-billed Seed-finch egg and one plasticine egg of the same size, shape and colors) to test the effects of egg size on nest predation risk. Nest and egg combinations were placed from 28 October to 12 November and 9 December to 24 December 2007, to test the temporal effects of the reproductive season. These periods were used to represent the beginning and end of the songbird breeding season. We placed the nests in two habitats, open-cerrado and Eucalyptus plantations, to test the effects of habitat type (open shrub vs. open forest) on the risk of predation. A total of 160 nests were used: 20 nests of each egg size per habitat during each time period. We use one nest transect for each habitat and the transects were separated by $>700 \mathrm{~m}$ and were $>50 \mathrm{~m}$ from the habitat edge. Nests were placed every $25 \mathrm{~m}$ alternating large egg and small egg nests. Eggs were placed in the nests $48 \mathrm{~h}$ after placing the nests in the field to avoid possible influence due to the researcher. The nest installation took some time, however, placing the eggs was fast and we tried to avoid pauses near the nests.

Nests were monitored every three or four days until they disappeared or 15 days, whichever came first. This time interval was based on the incubation period for many songbirds in the Cerrado (L. F. França, pers. comm.). We considered damaged nests, or with at least one broken or missing egg as a predation event. V-shaped marks on the plasticine eggs were considered to be made by birds. Marks showing different types of teeth, canines or incisors were attributed to mammals. Marks in an inverted U-shape, as well as uniform and sharp teeth imprinting were considered to be made by reptiles.

\section{Data analysis}

Following the information-theoretic approach (Burnham \& Anderson 1998), we developed 11 a priori candidate models to test our initial hypotheses. These models evaluate the potential effect of egg size (large or small), period (beginning or end), or habitat type 
(open-cerrado or Eucalyptus plantation). We considered simple linear models containing only one covariate to test the first three hypotheses independently. We used multiple linear additive models (egg + period, egg + habitat, habitat + period or egg + habitat + period) or interactive models (egg $\times$ period, egg $\times$ habitat or egg $\times$ habitat $\times$ period $)$ to considers the association between the previous hypotheses. A constant survival model (null model) was also included.

We used the MARK Program (White \& Burnham 1999) to run General Linear Models, that estimate the daily survival of artificial nests (Dinsmore et al. 2002), and to sort candidate models based on Akaike Information Criterion adjusted for small samples (AIC; Burnham \& Anderson 1998). The best-fit model was the one with the lowest $\mathrm{AIC}_{\mathrm{c}}$ value and models with $\Delta \mathrm{AIC}_{\mathrm{c}} \leq 2$ were considered to have substantial support to explain variation in the data (Burnham \& Anderson 1998). We used the daily nest survival of the best-fit model to estimate nest success based on 15 days of incubation.

\section{Results}

Two of 11 candidate models received substantial support to explain daily nest survival, both including effects of egg size and reproductive period (Table 1). All other combinations of explanatory variables resulted in models with low support $\left(\Delta \mathrm{AIC}_{\mathrm{c}}>2.00\right)$ and interactive models had less support than their similar additive model. Hence, model averaging was unnecessary. The best fit model was clearly better than the null model $\left(\triangle \mathrm{AIC} \mathrm{c}_{\mathrm{c}}=22.2\right)$ and about $80 \%$ weight was in the first two models (Table 1 ).

We used the best-fit model (egg + period) to estimate daily nest survival, since it was more parsimonious than the second model (egg $\times$ period). Daily Survival Estimate (DSE) was $0.82(95 \% \mathrm{CI}=0.76$ to 0.86 ) early and 0.91 ( 0.87 to 0.93$)$ late for large eggs, compared to DSE of 0.72 (0.65 to 0.78$)$ early and 0.84 ( 0.79 to 0.88$)$ late for small eggs. Therefore nests with large eggs had higher success estimates during both periods, and nest success was greater at the end of the reproductive season (Figure 1). Specifically, estimates of egg success increased for both egg sizes during breeding season, but to a greater extent for large eggs. While the difference between periods for large eggs was 0.18 , the difference for small eggs was 0.07 .

Plasticine eggs from 98 nests $(62 \%)$ were marked. Three taxa were recognized and birds were responsible for about $40 \%$ of predation events (Table 2). However, all treatments had similar predation on both egg sizes (Table 2).

\section{Discussion}

Small eggs were preyed on more than large eggs in our experiments with artificial nests in open habitats of Neotropics, which suggests that predators are relatively small and large quail eggs are difficult to handle and consume (Roper 1992). Similar results have been reported for temperate (Maier \& DeGraaf 2000, Coppedge et al. 2007) and neotropical forests (Alvarez \& Galetti 2007). Comparisons between artificial and natural nests also revealed the importance of controlling egg size (Roper 2003, Berry \& Lill 2003, Burke et al. 2004, Robinson et al. 2005). The importance of other characteristics such as egg color and scent seems marginal (review in Major \& Kendal 1996). Our results also support the hypothesis that egg size influences predation estimates in experimental studies with artificial nests. Moreover, our results indicate that this effect is probably common even when top predators (birds) are different from those commonly observed in other areas (mammals, snakes and lizards).

Lower predation of large eggs indicates that some predators cannot or do not take large eggs. Studies based on evidences of predation show that some small mammals are unable to consume quail eggs (Roper 1992, Haskell 1995, DeGraaf \& Maier 1996, Bayne \& Hobson 1999, Maier \& DeGraaf 2000). Small birds, such as the Black-capped Chickadee (Parus atricapillus) also seem to be unable to consume quail eggs (Maier \& DeGraaf 2001). Because birds seem to be important nest predators in the Cerrado (França \& Marini 2009a, França et al. 2009), it would be important to determine if some small Cerrado birds cannot consume large eggs which might explain the difference in predation rates between artificial and natural nests.

Our study found a greater survival rate of artificial nests at the end of the reproductive season, regardless of egg size. A previous study showed similar tendency for large eggs (quail eggs; França \& Marini 2009a). Surprisingly, studies of natural nests in the same region found declining nest survival rates as the breeding season progressed (Borges \& Marini 2010, Santos 2008). Artificial nests may be inaccurate for providing absolute nest predation rates on real nests, but may be sufficient for relative comparisons (Major \& Kendal 1996, Buler \& Hamilton 2000, Dion et al. 2000). However, our study showed that relative predation rates of artificial nests may not be correct for determining relative trends as compared to natural

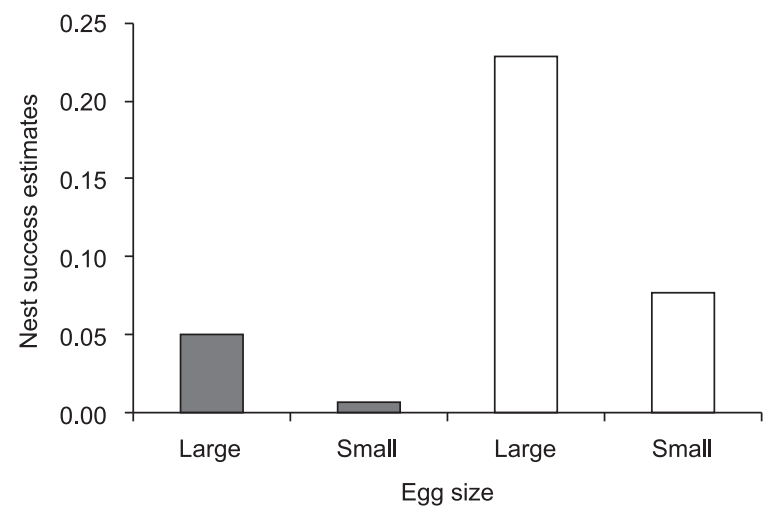

Figure 1. Success estimates of nests containing large or small eggs in the beginning (dark bars) and end (light bars) of the studied reproductive season. The equation of the best-adjusted model with one standard error in parentheses was $\operatorname{Logit}\left(\mathrm{S}_{\mathrm{i}}\right)=1.51(0.17)-0.59(0.19)_{\mathrm{egg}}+0.75(0.19)_{\text {period }}$. We used this model to estimates nest success based on 15 days of egg exposure.

Table 1. Candidate models for estimates daily survival of artificial bird nests (models with $\triangle \mathrm{AICc} \leq 10$ ). $\mathrm{AIC}_{\mathrm{c}}$ is the Akaike's Information Criterion, $\triangle \mathrm{AIC}$ is the difference between the $\mathrm{AIC}_{\mathrm{c}}$ of a model and the minimum $\mathrm{AIC}_{\mathrm{c}}$ found for the models, $k$ is the number of parameters, and $w$ - $\mathrm{AIC}$ is the support of each model in comparison to the others.

\begin{tabular}{|c|c|c|c|c|c|c|}
\hline Hypotheses & Model & $\mathrm{AIC}_{\mathrm{c}}$ & $\Delta \mathrm{AIC}_{\mathrm{c}}$ & $w-\mathrm{AIC}_{\mathrm{c}}$ & $\mathbf{k}$ & Deviance \\
\hline 1,2 & egg + period & 436.44 & 0.00 & 0.50 & 3 & 430.41 \\
\hline 1,2 & egg $\times$ period & 437.59 & 1.15 & 0.28 & 4 & 429.54 \\
\hline $1,2,3$ & egg + period + habitat & 438.46 & 2.02 & 0.18 & 4 & 430.41 \\
\hline $1,2,3$ & egg $\times$ period $\times$ habitat & 442.65 & 6.21 & 0.02 & 7 & 428.50 \\
\hline 2 & period & 443.98 & 7.54 & 0.01 & 2 & 439.97 \\
\hline 2,3 & period + habitat & 446.00 & 9.56 & 0.00 & 3 & 439.97 \\
\hline
\end{tabular}


Table 2. Percentage (and number) of plasticine eggs marked by different predators in the study area.

\begin{tabular}{lcc}
\hline \multirow{2}{*}{ Predator Taxon } & \multicolumn{2}{c}{ Percentage of Marked Eggs by Egg size } \\
\cline { 2 - 3 } & Large (n) & Small (n) \\
\hline Bird & $41(12)$ & $40(10)$ \\
Reptile & $21(6)$ & $20(5)$ \\
Mammal & $14(4)$ & $20(5)$ \\
Unidentified & $24(7)$ & $20(5)$ \\
Total & $100(29)$ & $100(25)$ \\
\hline
\end{tabular}

nests. That is, if natural nests do not follow the same trends over time as experimental nests, then the experimental nests do not describe what happens at natural nests. Therefore, controlling egg size in the experiments may not resolve the bias due to experimental nests. This hypothesis requires further attention in future studies on artificial nests in the Cerrado.

Predation rates were similar in the two habitat types despite the large differences in their structure (open shrub vs. open forest). Spatial variation in predation rates of artificial nests has been seen in similar as those in this study (Noske et al. 2008). For some passerines of the Cerrado, habitat type (natural vs. anthropic) or landscape characteristics (margin vs. interior) can affect nest success (Borges \& Marini 2010, França \& Marini 2009a). Despite comparisons with other studies, we did not reach conclusions concerning the lack of difference between habitat types in our experiment. We cannot say whether there was a discrepancy with observed for natural nests, since one of the habitats assessed (eucalyptus plantations) has no correspondence with natural habitats of the Cerrado.

Controlling for egg size to make experiments more realistic does not seem to be sufficient to make nest predation experiments valid in the Cerrado. We suggest that new studies based on simultaneous data from natural and artificial nests be developed to test the hypotheses on temporal pattern divergence between the nests (Roper 2003). Finally, it is important for new experiments to try to identify and compare predator assemblages of artificial and natural nests. This alternative may help explain specific sources of bias for the Cerrado, since birds were particularly important predators.

\section{Acknowledgements}

We would like to thank the graduate students who participated sporadically during fieldwork. We would also like to thank A. S. Mascarenhas-Filho, N. F. Macedo and R. C. Cambraia for the help in English.

\section{References}

ALVAREZ, A.D. \& GALETTI, M. 2007. Predação de ninhos artificiais em uma ilha na Mata Atlântica: testando o local e o tipo de ovo. Rev. Bras. Zool. 24(4):1011-1016. http://dx.doi.org/10.1590/S010181752007000400018

BATÁRY, P. \& BÁLDI, A. 2005. Factors affecting the survival of real and artificial great reed warbler's nests. Biol. Bratislava. 60(2):215-219.

BAYNE, E.M. \& HOBSON, K.A. 1999. Do clay eggs attract predators to artificial nests? J. Field Ornithol. 70(1):1-7.

BERRY, L. \& LILL, A. 2003. Do predation rates on artificial nests accurately predict predation rates on natural nests? The effects of nest type, egg type and nest-site characteristics. Emu. 103(3):207-214. http://dx.doi. org/10.1071/MU02054

BORGES, F.J.B. \& MARINI, M.Â. 2010. Birds nesting survival in disturbed and protected Neotropical savannas. Biodivers. Conserv. 19(1):223-236. http://dx.doi.org/10.1007/s10531-009-9718-z
BOYLE, W.A. 2008. Can variation in risk of nest predation explain altitudinal migration in tropical birds? Oecologia 155(2):397-403. http://dx.doi. org/10.1007/s00442-007-0897-6

BULER, J.J. \& HAMILTON, R.B. 2000. Predation of natural and artificial nests in a southern pine forest. Auk 117(3): 739-747. http://dx.doi. org/10.1642/0004-8038(2000)117[0739:PONAAN]2.0.CO;2

BURKE, D.M., ELLIOT, K., MOORE, L., DUNFORD, W., NOL, E., PHILLIPS, J., HOLMES, S. \& FREEMARK, K. 2004. Patterns of Nest Predation on Artificial and Natural Nests in Forests. Conserv. Biol. 18(2):381-388. http://dx.doi.org/10.1111/j.1523-1739.2004.00014.x

BURNHAM, K.P. \& ANDERSON, D.R. 1998. Model selection and inference: a practical information-theoretic approach. Springer-Verlag, New York. http://dx.doi.org/10.1007/978-1-4757-2917-7

CHIARELLO, A.G., SRBEK-ARAUJO, A.C., DEL DUQUE JUNIOR, H.J. \& COELHO, E.R. 2008. Ground nest predation might not be higher along edges of Neotropical forest remnants surrounded by pastures: evidence from the Brazilian Atlantic forest. Biodivers. Conserv. 17(13):3209-3221. http://dx.doi.org/10.1007/s10531-008-9422-4

COPPEDGE, B.R., TALENT, L.G. \& ENGLE, D.M. 2007. Effects of olfactory attributes and size of egg on rates of predation of artificial ground nests in Tallgrass Prairie. Southwest. Nat. 52(4):453-460. http://dx.doi. org/10.1894/0038-4909(2007)52[453:EOOAAS]2.0.CO;2

DEGRAAF, R.M. \& MAIER, T.J. 1996. Effect of egg size on predation by white-footed mice. Wilson Bull. 108(3):535-539.

DINSMORE, S.J., WHITE, G.C. \& KNOPF, F.L. 2002. Advanced techniques for modelling avian nest survival. Ecology. 83(12):3476-3488. http:// dx.doi.org/10.1890/0012-9658(2002)083[3476:ATFMAN]2.0.CO;2

DION, N., HOBSON, K.A. \& LARIVIERE, S. 2000. Interactive effects of vegetation and predators on the success of natural and simulated nests of grassland songbirds. Condor. 102(3): 629-634.

DUCA, C. \& MARINI, M. Â. 2005. Temporal variation in the reproductive success of Cacicus haemorrhous (Linnaeus) (Aves, Icterinae) in an Atlantic Forest reserve in Southeast Brazil. Rev. Bras. Zool. 22(2): 484-489. http:// dx.doi.org/10.1590/S0101-81752005000200026

FRANÇA, L.C. \& MARINI, M.Â. 2009a. Teste do efeito de borda na predação de ninhos naturais e artificiais no Cerrado. Rev. Bras. Zool. 26(2):241-250.

FRANÇA, L.F. \& MARINI, M.Â. 2009b. Low and variable reproductive success of a Neotropical tyrant-flycatcher, Chapada Flycatcher (Suiriri islerorum). Emu. 109(3):265-269. http://dx.doi.org/10.1071/MU09052

FRANÇA, L.F., SOUSA, N.O., SANTOS, L.R., DUCA, C., GRESSLER, D.T., BORGES, F.J.A., LOPES, L.E., MÂNICA, L.T., PAIVA, L.V., MEDEIROS, R.C.S. \& MARINI, M.Â. 2009. Passeriformes: nest predators and prey in a Neotropical Savannah in Central Brazil. Braz. J. Zoo. 26(4):799-802.

HASKELL, D.G. 1995. Forest fragmentation and nest predation: Are experiments with Japanese quail eggs misleading? Auk. 112(3):767-770.

LOPES, L.E. \& MARINI, M.Â. 2005. Low reproductive success of Campo Suiriri (Suiriri affinis) and Chapada Flycatcher (S. islerorum) in the Central Brazilian Cerrado. Bird Conserv. Inter. 15(4):337-346. http:// dx.doi.org/10.1017/S0959270905000675

MAIER, T.J. \& DEGRAAF, R.M. 2000. Predation on Japanese quail vs. House sparrow eggs in artificial nests: small eggs reveal small predators. Condor 102(2):325-332.

MAIER, T.J. \& DEGRAAF, R.M. 2001. Differences in depredation by small predators limit the use of plasticine and Zebra finch eggs in artificialnest studies. Condor 103(1):180-183. http://dx.doi.org/10.1650/00105422(2001)103[0180:DIDBSP]2.0.CO;2

MAJOR, R.E. \& KENDAL, C.E. 1996. The contribution of artificial nest experiments to understanding avian reproductive success: a review of methods and conclusions. Ibis 138(2):298-307. http://dx.doi.org/10.1111/ j.1474-919X.1996.tb04342.X

MEDEIROS, R.C.S. \& MARINI, M.Â. 2007. Biologia reprodutiva de Elaenia chiriquensis (Lawrence) (Aves, Tyrannidae) em Cerrado do Brasil Central. Rev. Bras. Zool. 24(1):12-20. http://dx.doi.org/10.1590/ S0101-81752007000100002 
MOORE, R.P. \& ROBINSON, W.D. 2004. Artificial bird nests, external validity, and bias in ecological field studies. Ecology 85(6):1562-1567. http://dx.doi.org/10.1890/03-0088

NOSKE, R.A., FISCHER, S. \& BROOK, B.W. 2008. Artificial nest predation rates vary among habitats in the Australian monsoon tropics. Ecol. Res. 23(3):519-527. http://dx.doi.org/10.1007/s11284-007-0403-y

PÄRT, T. \& WRETENBERG, J. 2002 Do artificial nests reveal relative nest predation risk for real nests? J Avian Biol. 33(1): 39-46. http://dx.doi. org/10.1034/j.1600-048X.2002.330107.x

RIBEIRO, J.F. \& WALTER, B.M.T. 1998. Fitofisionomias do bioma Cerrado. In Cerrado: ambiente e flora (S.M. Sano and S.P. Almeida, eds). Embrapa, Planaltina, p.89-166.

ROBINSON, W.D. \& ROBINSON, T.R. 2001. Observations of predation events at bird nests in Central Panama. J. Field Ornithol. 72(1):43-48.

ROBINSON, W.D., ROMPRE, G. \& ROBINSON, T.R. 2005. Videography of Panama bird nests shows snakes are principal predators. Ornitol. Neotrop. 16(2):187-195.

ROBINSON, W.D., ROBINSON, T.R., ROBINSON, S.K. \& BRAWN, J.D. 2000. Nesting Success of Understory Forest Birds in Central Panama. J. Avian Biol. 31(2):151-164. http://dx.doi.org/10.1034/j.1600048X.2000.310207.x

ROPER, J.J. 1992. Nest Predation Experiments With Quail Eggs: Too Much To Swallow? Oikos 63(3):528-530. http://dx.doi.org/10.2307/3545570
ROPER, J.J. 2000. Experimental analysis of nest-sites and nest predation for a neotropical bird: stuck between a rock and a hard place. Ararajuba 8(2):85-91.

ROPER, J.J. 2003. Nest-sites influence predation differently at natural and experimental nests. Ornitol. Neotrop. 14(1):1-14

RYDER, T.B., REITSMA, R., EVANS, B. \& MARRA, P.P. 2010. Quantifying avian nest survival along an urbanization gradient using citizen and scientist generated data. Ecol. Appl. 20(2):419-426. http://dx.doi. org/10.1890/09-0040.1

SANTOS, L.R. 2008. Biologia reprodutiva e comportamento cooperativo em ninhos de Cypsnagra hirundinacea. Master Science dissertation. Brasília University.

STAKE, M.M., FAABORG, J. \& THOMPSON, F.R. 2004. Video identification of predators at Golden-cheeked Warbler nests. J. Field Ornithol. 75(4):337-344.

STUTCHBURY, B.J.M. \& MORTON, E.S. 2001. Behavioral Ecology of Tropical Birds. Academic Press, San Diego.

WHELAN, C.J., DILGER, M.L., ROBSON, D., HALLYN, N. \& DILGER, S. 1994.Effects of Olfactory Cues on Artificial-Nest Experiments. Auk 111(4): 945-952. http://dx.doi.org/10.2307/4088826

WHITE, G.C. \& BURNHAM, K.P. 1999. Program MARK: survival estimation from populations of marked animals. Bird Study. 46(1):120-139. http:// dx.doi.org/10.1080/00063659909477239 